\title{
Anthropogenic structures as a spatial refuge from predation for the invasive bryozoan Bugula neritina
}

\author{
Clément P. Dumont ${ }^{1,2, *}$, Larry G. Harris ${ }^{3}$, Carlos F. Gaymer ${ }^{2}$ \\ ${ }^{1}$ The Swire Institute of Marine Science and the School of Biological Sciences, The University of Hong Kong, Hong Kong, \\ PR China \\ ${ }^{2}$ Centro de Estudios Avanzados en Zonas Áridas (CEAZA), and Departamento de Biología Marina, \\ Universidad Católica del Norte, Larrondo 1281, Coquimbo, Chile \\ ${ }^{3}$ Department of Biological Sciences, University of New Hampshire, Durham, New Hampshire 03824, USA
}

\begin{abstract}
Anthropogenic structures may play an important role in the marine invasion process by providing novel artificial habitats, often out of the reach of common benthic predators. A survey of piers in northern-central Chile revealed a change in the epibenthic assemblage on pilings at different distances from a rocky shore with abundant grazers and predators. Pilings on soft sediment, away from the rocky shore, were heavily colonized by the invasive bryozoan Bugula neritina. We therefore hypothesized that benthic predators may forage on pilings located on rocky bottom whereas pilings on soft sediment benefit from the absence of generalist benthic predators which do not occur on soft sediment. We examined piling communities using cages directly attached to pilings, where we included or excluded the sea urchin Tetrapygus niger and the rock shrimp Rhyncocinetes typus. Resultant communities differed substantially; a high percentage of bare space occurred in the presence of sea urchins, while turf algae dominated in the presence of shrimp. Both sea urchins and shrimp suppressed the colonization of the invasive $B$. neritina and, when acting together, totally prevented its recruitment. In contrast, invasive bryozoans colonized $95 \%$ of the available substratum in cages where predators were excluded. Our results show the important role of benthic generalist predators in limiting the establishment and spread of non-native species on anthropogenic structures. Further, this study highlights the unprecedented role of shrimp grazing in structuring hard-bottom communities.
\end{abstract}

KEY WORDS: Predation · Rock shrimp · Sea urchin $\cdot$ Invasive species $\cdot$ Fouling $\cdot$ Artificial habitat Resale or republication not permitted without written consent of the publisher

\section{INTRODUCTION}

Human activities are constantly increasing along coastal zones and are altering the habitat structure with anthropogenic infrastructures that change the diversity and abundance of species within benthic communities (Bulleri \& Chapman 2010). Marine assemblages on these novel artificial substrata differ substantially from those on natural benthic communities, raising major concerns about the consequences of such biodiversity changes (Glasby \& Connell 1999, Chapman \& Blockley 2009, Ruiz et al. 2009, Bulleri \& Chap- man 2010). In fact, it is common that introduced species dominate epibenthic communities on artificial structures (Stachowicz et al. 2002, Glasby et al. 2007, Sams \& Keough 2007, Dafforn et al. 2009) and eventually outcompete native species (Tyrrell \& Byers 2007). Further, introduced species have been more frequently reported on artificial hard substrata in estuaries and bays than on open coasts (Wasson et al. 2005, Ruiz et al. 2009, Marins et al. 2010). However, our understanding of the factors that contribute to the invasion processes on anthropogenic structures and subsequently to natural habitats remain limited despite numerous 
studies reporting an increasing number of non-native species in the marine environment (Ruiz et al. 2000, Robinson et al. 2005, Streftaris et al. 2005).

A number of studies have examined the abiotic factors that contribute to the development of fouling assemblages on artificial structures, including disturbance, orientation, position, material, motion, light and pollution (Harris \& Irons 1982, Glasby 1999, 2000, Glasby \& Connell 2001, Dobretsov et al. 2005, Blockley \& Chapman 2006, Cifuentes et al. 2007, Crooks et al. 2011), as well as biotic factors, e.g. recruitment, competition, and predation (Osman 1977, Sutherland \& Karlson 1977, Keough \& Downes 1982, Stachowicz et al. 1999, Tyrrell \& Byers 2007, Nydam \& Stachowicz 2007). Post-settlement predation is one important factor that can result in high mortality rates for newly settled marine invertebrates (Gosselin \& Qian 1997, Hunt \& Scheibling 1997). It is widely accepted that large generalist omnivores can actively graze on recruits settled on hard substrata and influence the development of benthic communities (Witman \& Dayton 2001). For example, intense grazing in benthic hardbottom communities by sea urchins can lead to barren zones dominated by encrusting coralline algae (Chapman 1981, Witman 1987, Andrew 1993). Several studies have shown that predation can have a dramatic effect on fouling community development when large predators (e.g. sea urchins, sea stars, crabs), but also micropredators (e.g. small gastropods), are present (Osman et al. 1992, Osman \& Whitlatch 1995, Osman \& Whitlatch 2004, Nydam \& Stachowicz 2007).

However, predators that are naturally abundant in benthic communities can be rare on artificial structures (Chapman 2003, Chapman \& Blockley 2009). Predators from rocky bottoms may colonize artificial structures that are connected to hard substrata. In contrast, common soft-bottom predators, many of which bury temporarily in the sediment (e.g. Reise 1985) may not colonize hard artificial structures. Consequently, artificial structures located on rocky substrata may be more accessible to benthic predators than ones on sandy substrata or suspended in the water column. In the present study, we first described the fouling communities found on pilings at different distances from the shore at La Herradura Bay, in northern-central Chile. Based on initial observations of the fouling communities, we hypothesized that pilings set on rocky bottom are provided with potential predators which forage on fouling communities, whereas communities on pilings found on soft sediment at increasing distances from the rocky shore have much fewer benthic predators such as rock shrimp and sea urchins, which rarely move across soft sediments. This should result in a greater impact on fouling community development near the shore (over rocky bottom) and less impact seaward (over sandy bottom). We performed a manipulative enclosure experiment to examine the effects of 2 abundant predators on rocky reefs (rock shrimp and sea urchins) in structuring fouling communities on pilings.

\section{MATERIALS AND METHODS}

Study site. The present study was conducted at La Herradura Bay, a $3.3 \mathrm{~km}^{2}$ sheltered bay in northerncentral Chile (Fig. 1), between October 2005 and Jan-

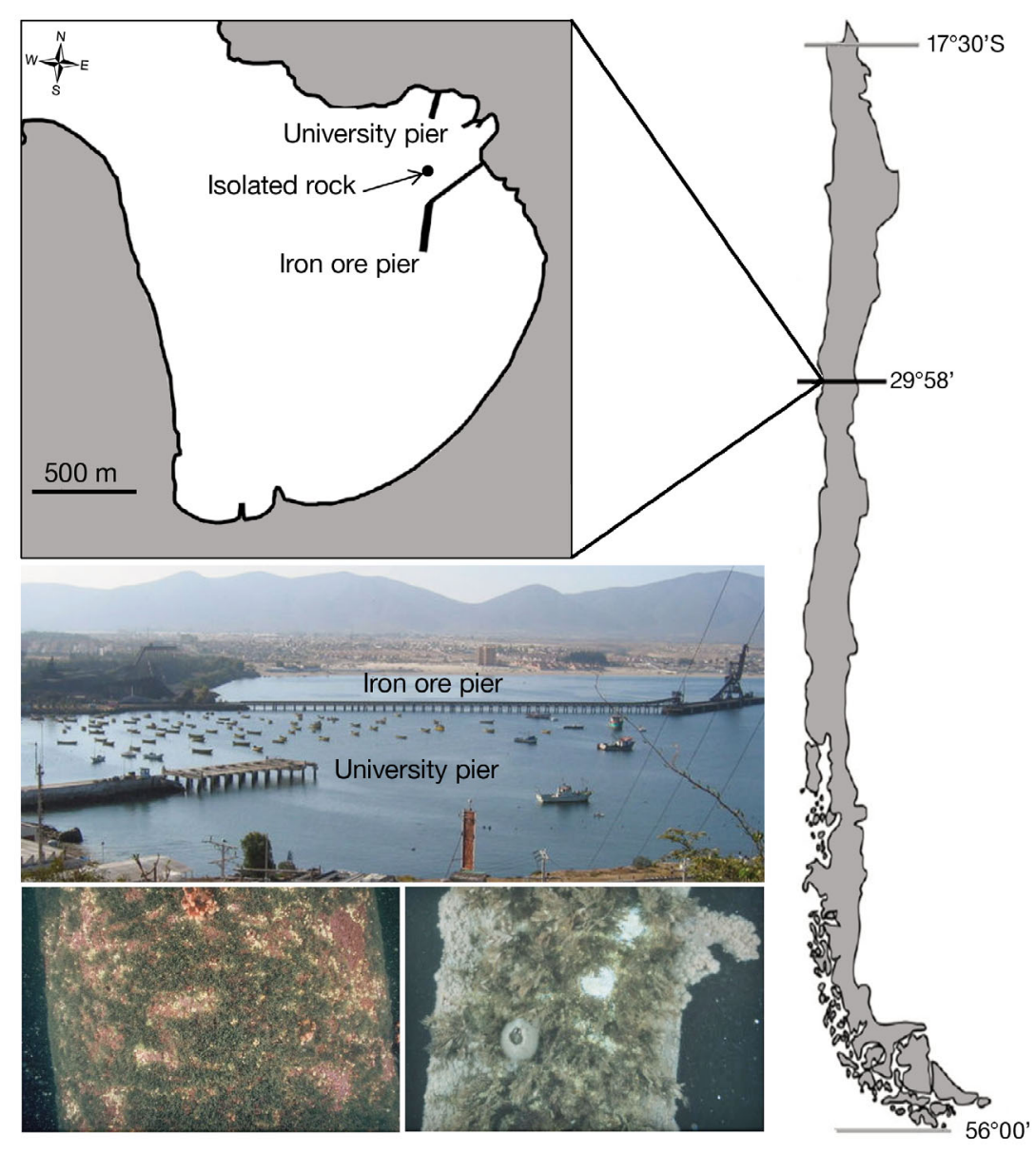

Fig. 1. Map of Chile and inset of La Herradura Bay noting the 2 piers and the isolated rock on sandy bottom where surveys and cage experiment were conducted. The bottom photographs show the piers, a piling set on boulders (left panel) and one set on sandy bottom (right panel) 
uary 2006. Large boulders covered with encrusting coralline and red and green macroalgae characterize shallow rocky bottoms in the bay. The black sea urchin Tetrapygus niger and the rock shrimp Rhyncocinetes typus are the most abundant grazers and predators in shallow subtidal areas but other mobile predators such as blennid fishes, crabs and sea stars are also present. $R$. typus is a common grazer in northern Chile (Caillaux \& Stotz 2003), with populations having increased in response to the overexploitation of fish predators (Godoy et al. 2010) and the present lack of interest in its commercial exploitation. This rock shrimp was heavily harvested until the 1950s with bait traps but was then replaced by offshore shrimp species harvested by trawling (Vasquez \& Castilla 1982). The sea urchin T. niger occurs in high densities on rocky bottoms but is absent on soft bottoms. Buoys, piers and other marine facilities provide artificial hard-substrata for dense assemblages of fouling species, typically dominated by bryozoans (the invasive Bugula neritina and B. fabellata), ascidians (the native Pyura chilensis and the invasive Ciona intestinalis), hydrozoans (Hydractinia spp.), and the native giant barnacle Austromegabalanus psittacus (Valdivia et al. 2005, Cifuentes et al. 2007).

Field survey. We first described the established epibiotic communities on concrete pilings at different distances from the shore on the University Católica del Norte's pier (Fig. 1). Nearshore pilings were set on rocky substratum whereas offshore pilings were set on coarse-grained sand. To describe the communities on pilings, we surveyed 7 sets of 4 pilings (representing 4 replicates) that were parallel to the shore at 2 to $4 \mathrm{~m}$ in depth, and the sets extended out from the shore by a distance of $5 \mathrm{~m}$ from each other (see Figs. $1 \& 2$ ). We took 1 photoquadrat of each piling at $1 \mathrm{~m}$ above the bottom using a Nikonos $\mathrm{V}$ mounted with a $15 \mathrm{~mm}$ lens and 2 strobes. The communities on the pilings were consistent from just above the substrate/piling interface to within $1 \mathrm{~m}$ of the low tide mark on the pilings. Twelve pilings were therefore monitored on rocks (20 to $30 \mathrm{~m}$ from the shore), 4 at the edge of the rocky and sandy bottom (35 m), and 12 on sand (40 to $50 \mathrm{~m})$. The percent cover of the different taxa and bare space were estimated using a grid of 60 regularly spaced points overlaying projected images of the photoquadrats, which represented an area of between 0.14 and $0.2 \mathrm{~m}^{2}$. Densities of sea urchins were quantified with four $0.5 \times 0.5 \mathrm{~m}$ randomly placed quadrats per piling, while the number of shrimp on each piling was visually estimated early in the afternoon.

A second photographic survey was conducted using the same method at a nearby pier used to load iron ore carriers and a large rock isolated from other hard surfaces by over $20 \mathrm{~m}$ of sandy substratum (Fig. 1). The rock ( $3 \mathrm{~m}$ in diameter and $1.5 \mathrm{~m}$ in height) contained neither shrimp nor urchins. The cement base of the iron ore pier was set in a rocky assemblage similar to the University pier, but most of the remaining pilings were set in sediment. Photoquadrats were taken of the rock (12 quadrats), pier base (9 quadrats) and of pilings extending out from the shore on sandy bottoms (13 quadrats). The isolated rock represented a natural exclusion experiment, while the pier base and pilings were a parallel arrangement to the University pier.

Predation enclosure experiment. To assess whether benthic predators affect the structure of the fouling communities and particularly the recruitment of the invasive bryozoan Bugula neritina, a cage experiment was performed on the pilings of the University pier. Predation levels were manipulated using 4 cage treatments: (1) predator exclusion cage, (2) urchin cage (each containing 3 enclosed sea urchins), (3) shrimp cage (containing 3 enclosed rock shrimp), and (4) no cage. To further examine whether the initial community influenced the recruitment of sessile species and the grazing effect of the predators, the cage treatments were combined with 2 levels of substratum (unscraped or scraped surface). The unscraped substratum (i.e. turf algal community) represented a piling surface in the presence of shrimp, while the scraped substratum (i.e. bare rock) resembled a piling surface in the presence of urchins. We predicted that the resultant community would change or remain similar according to the enclosed predator species and the initial community.

The experimental cages (35 units) were made with a $5 \mathrm{~mm}$ plastic mesh $(30 \times 30 \times 15 \mathrm{~cm})$, had no bottom, and were directly attached with ropes to the pilings at a depth of 2 to $3 \mathrm{~m}$ below the sea surface. All cage treatments were randomly assigned to a piling located on rocky bottom or sandy bottom but close to boulders (at a distance of 30 to $40 \mathrm{~m}$ from the shore, see Fig. 2), and then placed in a random direction around the piling (4 cage treatments on each of 10 pilings). The pilings used to assign the cage treatments were initially covered by a turf alga community on which numerous shrimp but very few urchins were foraging. To obtain the bare rock (scraped) substratum, the surface of pilings were scraped with a metallic brush prior to the experiment to remove established sessile epibiota, although a small cover of turf and encrusting coralline algae could remain attached. In the case of unscraped substratum, an additional treatment was conducted with 3 shrimp and 3 sea urchins enclosed in the same cage. The sea urchins Tetrapygus niger (40 to $50 \mathrm{~mm}$ in test diameter) were collected on surrounding boulders, while the rock shrimp Rhyncocinetes typus (15 to $20 \mathrm{~mm}$ in carapace length) were gently collected from pilings, using plastic Ziploc ${ }^{\circledR}$ bags and then placed immediately into the cages. The abundance (12 ind. $\mathrm{m}^{-2}$ ) of shrimp and sea urchins in the cages were 
within the range of densities occurring on barren habitats (Caillaux \& Stotz 2003, Gaymer et al. 2010). The cages were visited weekly to remove encrusting organisms from the outer surface of the cages and to replace missing shrimp (a minimum of 2 shrimp were always present in cages with enclosed shrimp) and sea urchins ( 2 dead urchins were replaced in 1 cage in the third week). The experiment (5 replicates per treatment) was run for $12 \mathrm{wk}$ to allow enough time for the communities to develop inside the cages.

After $12 \mathrm{wk}$, each replicate treatment was sampled in situ and abundances of benthic invertebrates and macroalgae were estimated. Primary cover (organisms attached directly to the pilings) and secondary cover (organisms attached to primary cover) were estimated for sessile organisms using a grid of 81 regularly spaced points within a $0.25 \times 0.25 \mathrm{~m}$ quadrat. We limited the sampling to the secondary cover when the primary cover was not directly visible. Taxa that were present in a replicate, but did not appear under any of the 81 measuring points, were assigned a cover of $0.5 \%$.

To compare cover of sessile organisms and algae among treatments, percent cover data for primary and secondary covers were combined for non-parametric multivariate analyses. Percent covers were used to examine whether differences existed in the composition and species frequency of the resultant fouling communities. We performed permutational multivariate ANOVA (PERMANOVA), using the statistical package PERMANOVA+ (Anderson et al. 2008) to estimate the pseudo- $F$ statistic with permutations. This statistic is an analog of the univariate Fisher's $F$ ratio. When appropriate, a posteriori pair-wise comparisons were made using Monte Carlo sampling (Anderson et al. 2008). Multivariate analyses were performed separately for each type of substratum (scraped and unscraped) on Bray-Curtis dissimilarities after a square-root transformation of the data using PRIMER 6 (Clarke \& Gorley 2006). Univariate analyses of variance were used to test the difference in percent cover of the dominant taxa and bare space with treatment and substratum as fixed factors. The treatment cage shrimp+urchins was excluded from univariate analyses to maintain a balanced design. Normality was tested with the Shapiro-Wilks test and homogeneity of variances was tested using the Levene test, and in cases where the assumptions were not met, ANOVAs were applied to both the raw and the rank-transformed data, as suggested by Conover (1980), and we present the results of the former when they were the same for the 2 analyses.

\section{RESULTS}

At the University pier, the black sea urchin Tetrapygus niger only occurred on the pilings that were located on rocky bottom with a maximum density of 42.7 ( $\pm 14.2 \mathrm{SE})$ ind. $\mathrm{m}^{-2}$ on the first pilings, while the rock shrimp Rhyncocinetes typus was abundant on all pilings (up to 250 ind. per piling) except for pilings set at a distance $>10 \mathrm{~m}$ from the rocky bottom (Fig. 2). The

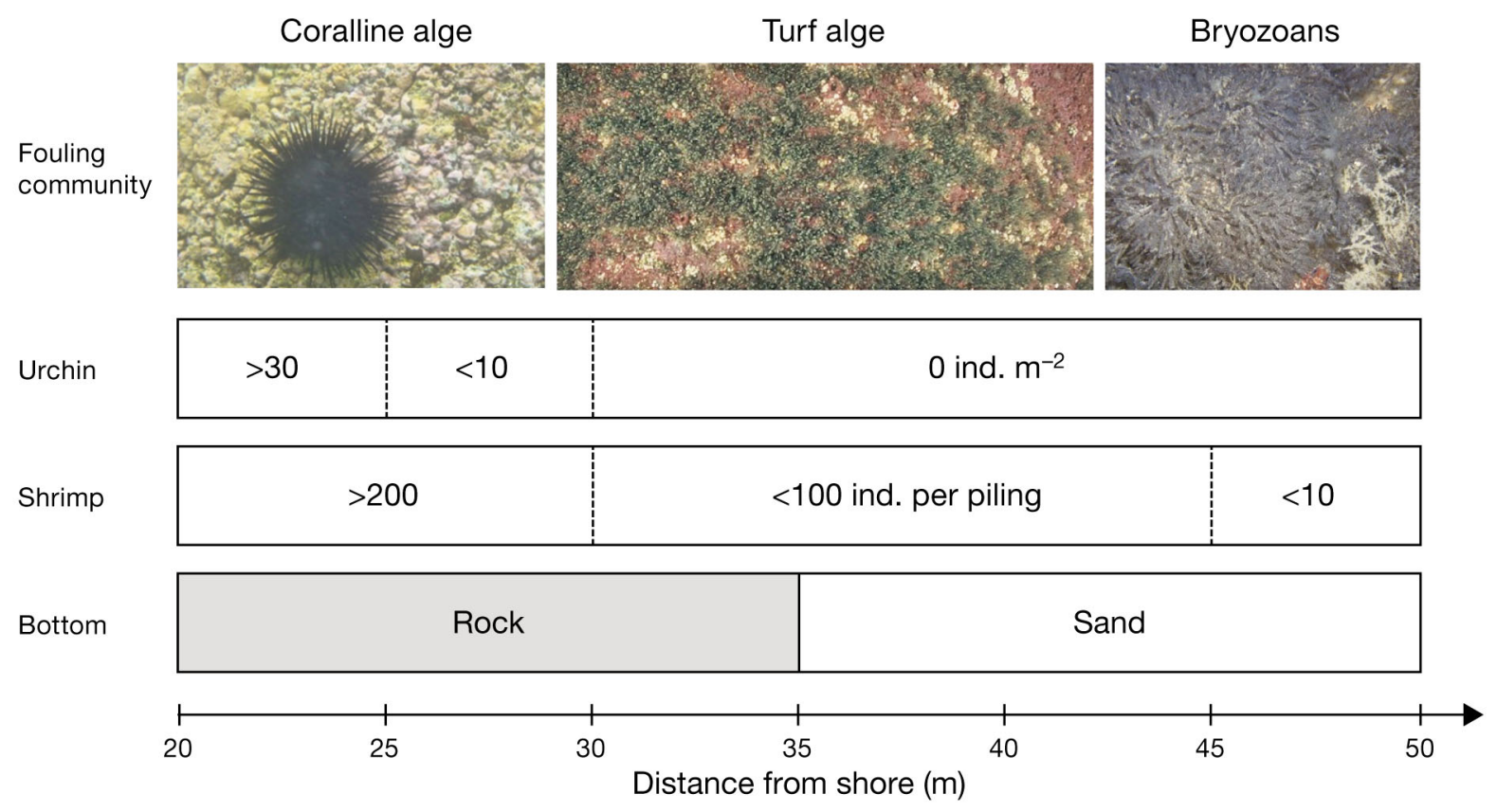

Fig. 2. Schematic distribution of sea urchins Tetrapygus niger, rock shrimp Rhyncocinetes typus and fouling community assemblages on pilings positioned on rocky or sandy bottom at different distances from the shore at the University pier at La Herradura Bay 
survey of the epibiotic assemblages on pilings revealed a gradient with encrusting coralline algae dominating on pilings with sea urchins, whereas a high cover of turf algae dominated on pilings where shrimp and few or no sea urchins were observed foraging (Figs. $2 \& 3$ ). In contrast, the furthest offshore pilings set on sandy bottom and in the presence of few shrimp and no sea urchins were heavily colonized by the invasive bryozoan Bugula neritina.

The survey of the iron ore pier showed a similar pattern to that of the University pier (Fig. 3). The base of the pier was dominated by encrusting corallines and small turf algae, and shrimp were conspicuous among the rocks surrounding the base. The pilings set on sand were dominated by a mix of Bugula neritina, the encrusting hydroid Hydractinia sp., and turf algae. The isolated rock had a mix of fleshy algae and colonies of $B$. neritina, which are not commonly found on algaldominated upper horizontal natural surfaces. No urchins or shrimp were observed on this rock between November 2005 and January 2006 during 3 visits spanning several weeks.

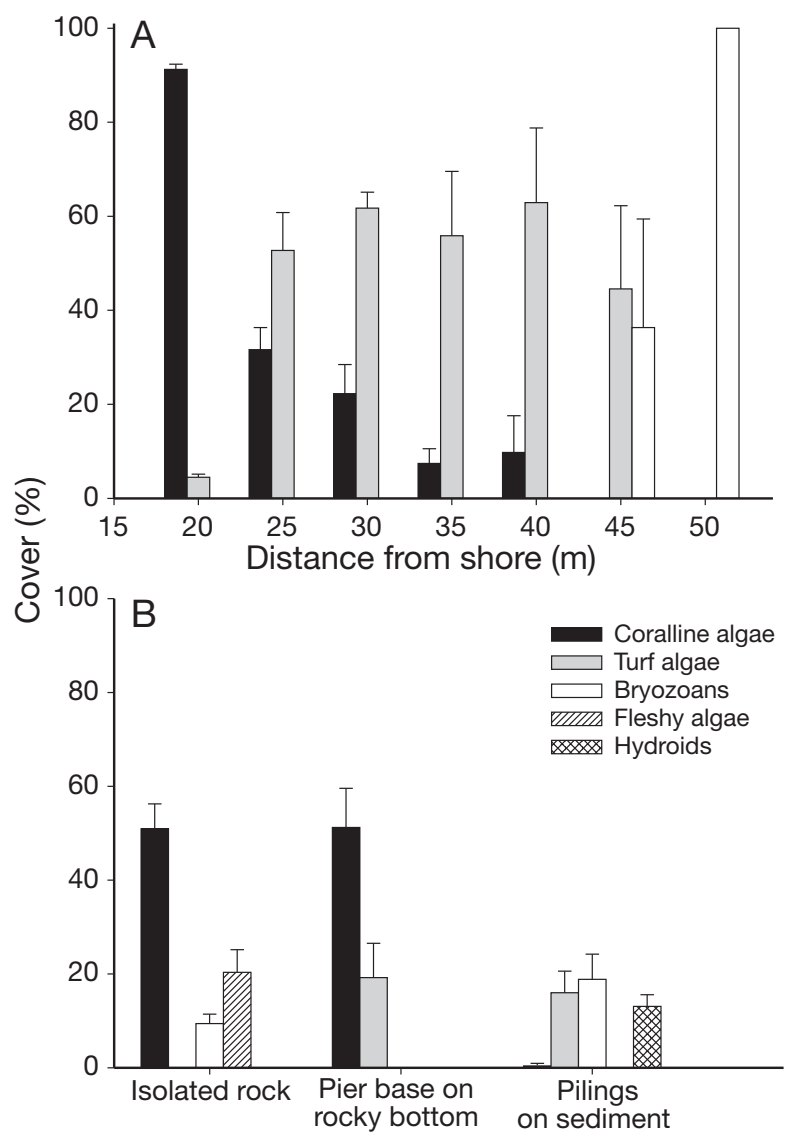

Fig. 3. Percent cover $( \pm$ SE) of main taxa occurring (A) on pilings set at different distances from the shore at the University pier at La Herradura Bay, and (B) on a rock isolated on sandy bottom, base and pilings of the iron ore pier at La Herradura Bay. The bryozoans include the invasive Bugula neritina and B. fabellata
The cage experiment resulted in the development of 3 distinct epibiotic assemblages i.e. communities dominated by encrusting coralline algae, turf algae or bryozoans (Fig. 4). The presence of the predators, sea urchins and rock shrimp, had a significant effect in limiting the recruitment of the invasive bryozoan (Table 1). In the predator exclusion cages, Bugula neritina monopolized cage substrata ( $>95 \%$ cover) on both scraped and unscraped surfaces. Such dominance by bryozoans resulted in only sporadic recruitment ( $<10 \%$ cover) of other sessile species such as serpulids (Fig. 5) and on a few occasions $(<1 \%)$ the invasive ascidian Ciona intestinalis. In contrast, no or low recruitment of bryozoans occurred in the presence of predators. Instead, the enclosures with shrimp resulted in a high cover of turf algae $(77.0 \pm 6.3 \%$ and $52.1 \pm$ $9.6 \%$ on scraped and unscraped surfaces, respectively) and some bryozoans (Table 2, Fig. 4). Turf algae also dominated in the uncaged treatment $(>80 \%$ for both scraped and unscraped surfaces), but no bryozoans

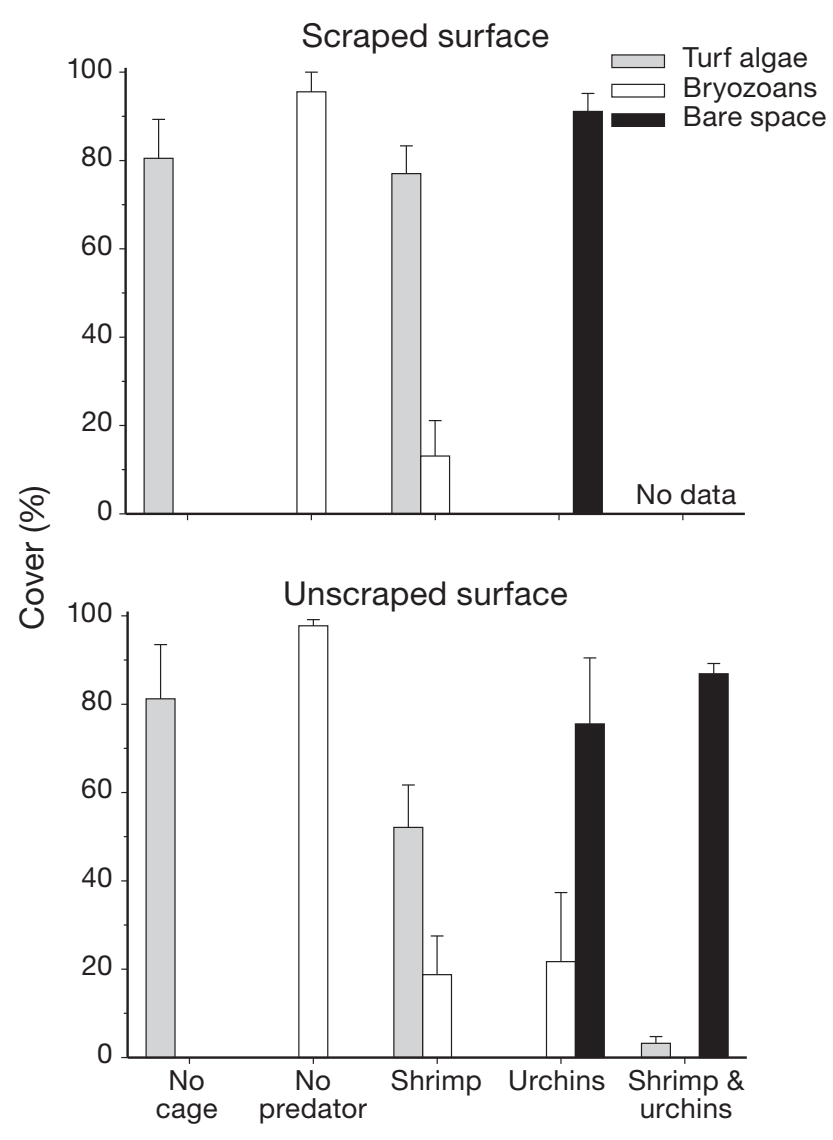

Fig. 4. Percent cover of the turf algae, bryozoans and bare space $(0.25 \times 0.25 \mathrm{~m}, \pm \mathrm{SE})$ at the end of a 3 mo predator enclosure experiment on pilings. Treatments were absence of cage, cage without predators, cage with shrimp, urchins, and shrimp+sea urchins. The surface of pilings were scraped (i.e. sessile species removal) or unscraped (i.e. remained intact) prior to starting the experiment 
Table 1. Statistical summary of permutational multivariate ANOVA and pair-wise a posteriori comparisons to test the effect of benthic predators on the fouling communities of pilings for each type of substrate (scraped and unscraped) using percent cover of sessile species. The treatments were no cage, no predator, cage with urchins, cage with shrimp, and cage with both urchins and shrimp for unscraped substrate. Separate analyses were run for each type of substratum (scraped and unscraped). p-values were estimated with Monte Carlo sampling. Pair-wise comparisons are indicated with the degree of similarity between the 2 treatments tested

\begin{tabular}{|c|c|c|c|}
\hline $\begin{array}{l}\text { Scraped substratum } \\
\text { Source }\end{array}$ & df & MS & Pseudo-F \\
\hline $\begin{array}{l}\text { Treatment } \\
\text { Error }\end{array}$ & $\begin{array}{r}3 \\
16\end{array}$ & $\begin{array}{r}13061.0 \\
347.9\end{array}$ & 0.0001 \\
\hline Pair-wise comparisons & $t$ & $\mathrm{p}$ & Similarity (\%) \\
\hline $\begin{array}{l}\text { No cage, No predator } \\
\text { No cage, Urchins } \\
\text { No cage, Shrimp } \\
\text { No predator, Urchins } \\
\text { No predator, Shrimp } \\
\text { Urchins, Shrimp }\end{array}$ & $\begin{array}{l}7.5 \\
7.4 \\
1.2 \\
9.6 \\
5.3 \\
6.3\end{array}$ & $\begin{array}{l}0.007 \\
0.008 \\
0.287 \\
0.008 \\
0.008 \\
0.006\end{array}$ & $\begin{array}{l}14.0 \\
18.8 \\
68.5 \\
15.1 \\
28.4 \\
17.6\end{array}$ \\
\hline $\begin{array}{l}\text { Unscraped substratum } \\
\text { Source }\end{array}$ & df & MS & Pseudo- $F \quad p$ \\
\hline $\begin{array}{l}\text { Treatment } \\
\text { Error }\end{array}$ & $\begin{array}{c}4 \\
20\end{array}$ & $\begin{array}{r}9108.7 \\
385.3\end{array}$ & 0.0001 \\
\hline Pair-wise comparisons & $t$ & $\mathrm{p}$ & Similarity (\%) \\
\hline $\begin{array}{l}\text { No cage, No predator (NP) } \\
\text { No cage, Urchins (U) } \\
\text { No cage, Shrimp (S) } \\
\text { No cage, U + S } \\
\text { NP, U } \\
\text { NP, S } \\
\text { NP, U + S } \\
\text { U, S } \\
\text { U, U + S } \\
\text { S, U + S }\end{array}$ & $\begin{array}{l}7.3 \\
5.2 \\
2.2 \\
6.3 \\
5.2 \\
4.5 \\
9.5 \\
3.9 \\
1.9 \\
4.3\end{array}$ & $\begin{array}{r}<0.001 \\
<0.001 \\
0.010 \\
<0.001 \\
<0.001 \\
<0.001 \\
<0.001 \\
<0.001 \\
0.051 \\
<0.001\end{array}$ & $\begin{array}{l}21.2 \\
21.7 \\
56.1 \\
23.2 \\
42.5 \\
42.3 \\
26.4 \\
33.2 \\
70.5 \\
37.6\end{array}$ \\
\hline
\end{tabular}

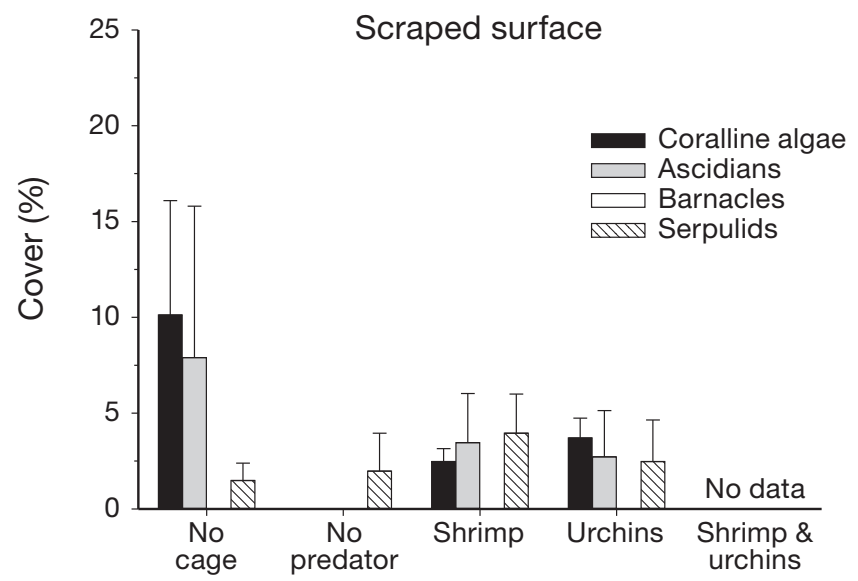

Table 2. Results of 2-way ANOVAs testing for the effects of benthic predators (cage with no predator, shrimp, sea urchins, and no cage) and the type of substrate (scraped and unscraped) on the percent cover of turf algae, the invasive bryozoan Bugula neritina and bare space on pilings. Results of Tukey's tests are presented below analyses with the abbreviations: NC, no cage; NP, no predator; $\mathrm{S}$, shrimp; U, sea urchin

\begin{tabular}{|c|c|c|c|c|}
\hline Source & $\mathrm{df}$ & MS & $F$ & $\mathrm{p}$ \\
\hline \multicolumn{5}{|l|}{ Turf algae } \\
\hline Treatment (T) & 3 & 18068 & 80.31 & $<0.001$ \\
\hline Substrate (S) & 1 & 366 & 1.63 & 0.211 \\
\hline $\mathrm{T} \times \mathrm{S}$ & 3 & 397 & 1.76 & 0.174 \\
\hline Residual & 32 & \multicolumn{3}{|c|}{$\mathrm{T}: \mathrm{NC}=\mathrm{S}>\mathrm{U}=\mathrm{NP}$} \\
\hline \multicolumn{5}{|l|}{ Bryozoans } \\
\hline Treatment $(\mathrm{T})$ & 3 & 19578 & 76.90 & $<0.001$ \\
\hline Substrate (S) & 1 & 531 & 2.08 & 0.159 \\
\hline $\mathrm{T} \times \mathrm{S}$ & 3 & 246 & 0.97 & 0.421 \\
\hline Residual & 32 & \multicolumn{3}{|c|}{$\mathrm{T}: \mathrm{NP}>\mathrm{S}=\mathrm{U}=\mathrm{NC}$} \\
\hline \multicolumn{5}{|l|}{ Bare space } \\
\hline Treatment $(\mathrm{T})$ & 3 & 17361 & 116.17 & $<0.001$ \\
\hline Substrate (S) & 1 & 151 & 1.01 & 0.322 \\
\hline $\mathrm{T} \times \mathrm{S}$ & 3 & 151 & 1.01 & 0.400 \\
\hline Residual & 32 & \multicolumn{3}{|c|}{$\mathrm{T}: \mathrm{NP}>\mathrm{S}=\mathrm{U}=\mathrm{NC}$} \\
\hline
\end{tabular}

were found in those communities. In the presence of sea urchins, bare space largely dominated on both scraped and unscraped surfaces (Table 2, Fig. 4). The additive treatment with urchins and shrimp on unscraped surfaces also resulted in a high proportion of bare space $(86.9 \pm 2.4 \%)$, relatively similar to the unscraped treatment with urchins only $(\mathrm{p}=0.051$, Table 1). However, the latter did not prevent the recruitment of bryozoans, contrary to the enclosure with urchins and shrimps (Fig. 4).

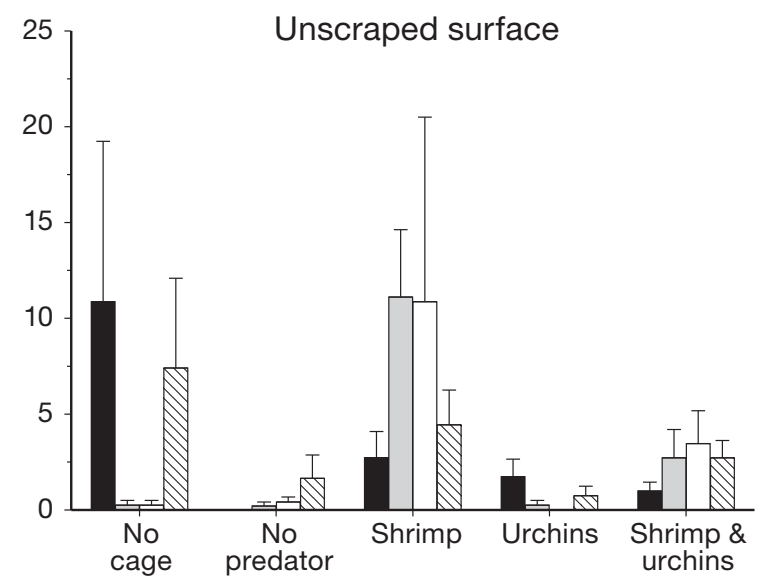

Fig. 5. Percent cover $(0.25 \times 0.25 \mathrm{~m}, \pm \mathrm{SE})$ of serpulids Spirorbis sp., solitary (Pyura chilensis) and colonial ascidians, barnacles and coralline algae at the end of a 3 mo predator enclosure experiment on pilings. Treatments were absence of cage, cage without predators, cage with shrimp, urchins, and shrimp+sea urchins. The surface of pilings was scraped (i.e. sessile species removal) or unscraped (i.e. remained intact) prior to starting the experiment 


\section{DISCUSSION}

The high abundance and diversity of non-native species on anthropogenic structures (Glasby \& Connell 1999, Holloway \& Connell 2002, Bulleri \& Chapman 2010) suggest that these artificial substrata could provide a spatial refuge from predation. Our study demonstrates that anthropogenic structures (i.e. pier pilings) can facilitate the establishment of the invasive erect bryozoan Bugula neritina by supplying novel substrata out of reach of benthic predators. The field survey at the 2 piers revealed that pilings set on a rocky bottom were colonized by a fouling community dominated by coralline and turf algae, while pilings surrounded by sandy bottoms at a distance from the rocky shore were heavily colonized by $B$. neritina. This change in fouling community composition correlated with the presence of benthic predators on the pilings. Sea urchins and rock shrimp were present on the first pilings located on boulders from which these benthic predators could easily forage. Predators decreased in abundance on offshore pilings with the replacement of rocky substrata with sandy bottom.

Numerous studies have reported an increase in ascidians and bryozoans in cage experiments in fouling communities (e.g. Russ 1980, Table 3 in Schmidt \& Warner 1984). Similarly, in our study conducted during the recruitment period of Bugula neritina (Cifuentes et al. 2010), the exclusion of predators within cages on pilings resulted in a high recruitment of bryozoans largely dominated by this invasive species. We further observed numerous adult colonies of $B$. neritina on an isolated rock in a sandy area, indicating that this invasive bryozoan can occupy natural benthic communities when grazers (e.g. sea urchins, shrimp) are not present. Thus, anthropogenic structures away from rocky bottom (e.g. pilings on soft substratum, floating structures) offer epibiotic species a spatial refuge from numerous invertebrate benthic predators. The sea urchins and shrimp prevented the colonization of $B$. neritina, but only to a limited distance from their rocky habitat. While sea urchins remained relatively sedentary on pilings, shrimp seek refuge from predators within boulders on the rocky shore and make short-distance movements outside of their shelters to forage on pilings. The higher mobility of shrimp compared to sea urchins allows them to forage further away from the rocky bottom (i.e. on distant pilings) and consequently influence the development of fouling communities on offshore pilings. The confounding factor depth could also possibly have influenced the observed patterns. However, the bottom slope in the back part of La Herradura Bay is very slight and the depth of the pilings on sand only varied by less than $2 \mathrm{~m}$ from the rocks to the outer edge of the pilings, so distance from the shore was most likely the important factor.
Predation strongly affected the development of the fouling assemblages but the resultant communities differed with predator species. Sea urchins graze on algae and invertebrate recruits, including bryozoans. Shrimp, with their slender and tweezer-like second chelipeds, can more carefully select the food of interest and do not necessarily damage other recruits. The presence of bryozoan recruits in cages with shrimp suggests that a higher density would have been necessary in the enclosures (12 ind. $\mathrm{m}^{-2}$ ) to totally suppress the recruitment of Bugula neritina. The heterogeneity of the substratum (i.e. unscraped pilings) also likely restricted the sea urchins from grazing on bryozoans that recruited within interstices created by engineer species such as ascidians and barnacles (Castilla et al. 2004). However, the combination of the 2 predators (sea urchins and shrimp) enhanced their effectiveness in preventing the recruitment of the invasive bryozoans due to the ability of shrimp to forage on organisms recruiting within interstices.

The ecological importance of rock shrimp in benthic marine systems is largely unknown. In stream ecosystems, freshwater shrimp are often the dominant macro-consumers and can play an important role in determining the benthic community assemblages (Pringle et al. 1993, March et al. 2002). In seagrass beds, shrimp actively graze on epibionts (both plant and animal) on grass blades, which influences the development of epibionts in seagrass communities (Persson et al. 2008). In rocky reef communities, however, shrimps are usually not considered important predators (but see Bruno \& O'Connor 2005). Our results clearly show the dramatic effect of rock shrimp on the development of epibenthic communities, which may therefore play an important role in structuring the benthic communities in northern Chile. Shrimp foraging may further prevent introduced species such as Bugula neritina from invading benthic communities. However, it remains unclear how Rhyncocinetes typus interacts with other intermediate consumers (e.g. sea urchins). Its reported voracity in feeding on invertebrates such as the introduced cultured Japanese abalone (Stotz et al. 2006) and small recruits of sea urchins (C. Dumont pers. obs.), and its ability to effectively consume fouling organisms on pearl nets of scallop aquaculture (Dumont et al. 2009) suggest an important functional role of shrimp in controlling benthic assemblages. Given the importance of $R$. typus grazing on fouling communities, further studies are required to elucidate the ecological role of this abundant species in natural habitats (Caillaux \& Stotz 2003). Several studies have demonstrated that predators can limit the abundance or distribution of invaders in natural habitats (e.g. Byers 2002, Hunt \& Yamada 2003, Castilla et al. 2004, deRivera et al. 2005). Similarly, the shrimp R. typus 
could certainly contribute to the biotic resistance of invasions in rocky habitats in northern Chile.

A number of studies have shown that predation may strongly influence the development of fouling communities (Russ 1980, Mook 1981, Anderson \& Underwood 1997, Osman \& Whitlatch 2004, Nydam \& Stachowicz 2007), while others have reported weak effects of predation (Keough \& Butler 1979, Connell 2001, Sams \& Keough 2007). The effect of benthic predators on community development varies with the type of structures (e.g. piling versus floating structures, Holloway \& Connell 2002), but our study further shows that the type of surrounding benthic substratum determines the access of benthic predators that can affect the development of the fouling community and, more importantly, the spread of invasive species. In fact, such anthropogenic structures are frequently located in protected bays and estuaries dominated by sandy or muddy bottoms, but it is also common to have either natural or artificial shallow rocky fringes in such bays. There is no question that other environmental factors contribute to the structure of fouling communities (see 'Introduction'), but our results highlight the importance of the substratum surrounding these pilings and other artificial substrata, and indicate that benthic invertebrate predators may determine the fouling community on these solid structures where they can access them from nearby rocky bottoms.

Acknowledgements. Financial support for this study was provided by Fulbright to L.G.H. a Fondecyt 3030007 grant to C.F.G. and a Programa Bicentenario de Ciencia y Tecnología grant to CEAZA. We thank J. Barrios, who helped with diving activities, and $\mathrm{M}$. Thiel and 3 reviewers for providing critical comments on this manuscript.

\section{LITERATURE CITED}

Anderson MJ, Underwood AJ (1997) Effects of gastropod grazers on recruitment and succession of an estuarine assemblage: a multivariate and univariate approach. Oecologia 109:442-453

Anderson MJ, Gorley RN, Clarke KR (2008) PERMANOVA+ for PRIMER: guide to software and statistical methods. PRIMER-E, Plymouth

Andrew NL (1993) Spatial heterogeneity, sea urchin grazing, and habitat structure on reefs in temperate Australia. Ecology 74:292-302

Blockley D, Chapman M (2006) Recruitment determines differences between assemblages on shaded or unshaded seawalls. Mar Ecol Prog Ser 327:27-36

Bruno JF, O'Connor MI (2005) Cascading effects of predator diversity and omnivory in a marine food web. Ecol Lett 8: 1048-1056

Bulleri F, Chapman M (2010) The introduction of coastal infrastructure as a driver of change in marine environments. J Appl Ecol 47:26-35

Byers JE (2002) Physical habitat attribute mediates biotic resistance to non-indigenous species invasion. Oecologia 130:146-156
Caillaux LM, Stotz WB (2003) Distribution and abundance of Rhynchocinetes typus (Crustacea: Decapoda), in different benthic community structures in northern Chile. J Mar Biol Assoc UK 83:143-150

Castilla JC, Lagos NA, Cerda M (2004) Marine ecosystem engineering by the alien ascidian Pyura praeputialis on a mid-intertidal rocky shore. Mar Ecol Prog Ser 268:119-130

Chapman ARO (1981) Stability of sea urchin dominated barren grounds following destructive grazing of kelp in St. Margaret's bay, Eastern Canada. Mar Biol 62:307-311

> Chapman MG (2003) Paucity of mobile species on constructed seawalls: effects of urbanization on biodiversity. Mar Ecol Prog Ser 264:21-29

Chapman MG, Blockley DJ (2009) Engineering novel habitats on urban infrastructure to increase intertidal biodiversity. Oecologia 161:625-635

Cifuentes M, Kamlah C, Thiel M, Lenz M, Wahl M (2007) Effects of temporal variability of disturbance on the succession in marine fouling communities in northern-central Chile. J Exp Mar Biol Ecol 352:280-294

Cifuentes M, Krueger I, Dumont CP, Lenz M, Thiel M (2010) Does primary colonization or community structure determine the succession of fouling communities? J Exp Mar Biol Ecol 395:10-20

Clarke K, Gorley R (2006) PRIMER v6: user manual/tutorial. PRIMER-E, Plymouth

> Connell SD (2001) Predatory fish do not always affect the early development of epibiotic assemblages. J Exp Mar Biol Ecol 260:1-12

Conover WJ (1980) Practical nonparametric statistics. John Wiley and Sons, New York, NY

Crooks J, Chang A, Ruiz G (2011) Aquatic pollution increases the relative success of invasive species. Biol Invasions 13: 165-176

Dafforn KA, Johnston EL, Glasby TM (2009) Shallow moving structures promote marine invader dominance. Biofouling 25:277-287

deRivera CE, Ruiz GM, Hines AH, Jivoff P (2005) Biotic resistance to invasion: native predator limits abundance and distribution of an introduced crab. Ecology 86:3364-3376

> Dobretsov SV, Qian PY, Wahl M (2005) Effect of solar ultraviolet radiation on the formation of shallow, early successional biofouling communities in Hong Kong. Mar Ecol Prog Ser 290:55-65

> Dumont CP, Urriago JD, Abarca A, Gaymer CF, Thiel M (2009) The native rock shrimp Rhynchocinetes typus as a biological control of fouling in suspended scallop cultures. Aquaculture 292:74-79

Gaymer CF, Palma AT, Vega JMA, Monaco CJ, Henríquez LA (2010) Effects of La Niña on recruitment and abundance of juveniles and adults of benthic community-structuring species in northern Chile. Mar Freshw Res 61:1185-1196

Glasby TM (1999) Effects of shading on subtidal epibiotic assemblages. J Exp Mar Biol Ecol 234:275-290

> Glasby TM (2000) Surface composition and orientation interact to affect subtidal epibiota. J Exp Mar Biol Ecol 248: $177-190$

Glasby TM, Connell SD (1999) Urban structures as marine habitats. Ambio 28:595-598

Glasby TM, Connell SD (2001) Orientation and position of substrata have large effects on epibiotic assemblages. Mar Ecol Prog Ser 214:127-135

> Glasby TM, Connell SD, Holloway MG, Hewitt CL (2007) Nonindigenous biota on artificial structures: Could habitat creation facilitate biological invasions? Mar Biol 151: 887-895

Godoy N, Gelcich S, Vasquez JA, Castilla JC (2010) Spear- 
fishing to depletion: evidence from temperate reef fishes in Chile. Ecol Appl 20:1504-1511

Gosselin LA, Qian P (1997) Juvenile mortality in benthic marine invertebrates. Mar Ecol Prog Ser 146:265-282

Harris LG, Irons KP (1982) Substrate angle and predation as determinants in fouling community succession. In: Cairns J (ed) Artificial substrates. Ann Arbor Science Publishers, Ann Arbor, MI, p 243-248

Holloway MG, Connell SD (2002) Why do floating structures create novel habitats for subtidal epibiota? Mar Ecol Prog Ser 235:43-52

Hunt HL, Scheibling RE (1997) Role of early post-settlement mortality in recruitement of benthic marine invertebrates. Mar Ecol Prog Ser 155:269-301

Hunt C, Yamada S (2003) Biotic resistance experienced by an invasive crustacean in a temperate estuary. Biol Invasions 5:33-43

Keough M, Butler A (1979) The role of asteroid predators in the organization of a sessile community on pier pilings. Mar Biol 51:167-177

Keough MJ, Downes BJ (1982) Recruitment of marine invertebrates: the role of active larval choices and early mortality. Oecologia 54:348-352

March JG, Pringle CM, Townsend MJ, Wilson AI (2002) Effects of freshwater shrimp assemblages on benthic communities along an altitudinal gradient of a tropical island stream. Freshw Biol 47:377-390

Marins FO, Novaes RLM, Rocha RM, Junqueira AOR (2010) Non indigenous ascidians in port and natural environments in a tropical Brazilian bay. Zoologia 27:213-221

Mook D (1981) Effects of disturbance and initial settlement on fouling community structure. Ecology 62:522-526

Nydam M, Stachowicz JJ (2007) Predator effects on fouling community development. Mar Ecol Prog Ser 337:93-101

Osman R (1977) The establishment and development of a marine epifaunal community. Ecol Monogr 47:37-63

Osman RW, Whitlatch RB (1995) Predation on early ontogenic life stage and its effect on recruitment into a marine epifaunal community. Mar Ecol Prog Ser 117:111-126

Osman RW, Whitlatch RB (2004) The control of the development of a marine benthic community by predation on recruits. J Exp Mar Biol Ecol 311:117-145

Osman RW, Whitlatch RB, Malatesta RJ (1992) Potential role of micropredators in determining recruitment into a marine community. Mar Ecol Prog Ser 83:35-43

Persson M, Andersson S, Baden S, Moksnes P (2008) Trophic role of the omnivorous grass shrimp Palaemon elegans in a Swedish eelgrass system. Mar Ecol Prog Ser 371: 203-212

Pringle C, Blake G, Covich A, Buzby K, Finley A (1993) Effects of omnivorous shrimp in a montane tropical stream: sediment removal, disturbance of sessile invertebrates and enhancement of understory algal biomass. Oecologia 93:1-11

Reise K (1985) Tidal flat ecology: an experimental approach to species interactions. Springer Verlag, Berlin

Robinson TB, Griffiths CL, McQuaid C, Rius M (2005) Marine alien species of South Africa - status and impacts. Afr J

Editorial responsibility: Richard Osman,

Edgewater, Maryland, USA
Mar Sci 27:297-306

Ruiz GM, Fofonoff PW, Carlton JT, Wonham MJ, Hines AH (2000) Invasion of coastal marine communities in North America: apparent patterns, processes, and biases. Annu Rev Ecol Syst 31:481-531

Ruiz G, Freestone A, Fofonoff P, Simkanin C (2009) Habitat distribution and heterogeneity in marine invasion dynamics: the importance of hard substrate and artificial structure. In: Wahl M (ed) Marine hard bottom communities. Springer, Berlin, p 321-332

Russ GR (1980) Effects of predation by fishes, competition, and structural complexity of the substratum on the establishment of a marine epifaunal community. J Exp Mar Biol Ecol 42:55-69

Sams MA, Keough MJ (2007) Predation during early postsettlement varies in importance for shaping marine sessile communities. Mar Ecol Prog Ser 348:85-101

Schmidt G, Warner G (1984) Effects of caging on the development of a sessile epifaunal community. Mar Ecol Prog Ser $15: 251-263$

Stachowicz JJ, Whitlatch RB, Osman RW (1999) Species diversity and invasion resistance in a marine ecosystem. Science 286:1577-1579

Stachowicz JJ, Fried H, Osman RW, Whitlatch RB (2002) Biodiversity, invasion resistance, and marine ecosystem function: reconciling pattern and process. Ecology 83:2575-2590

> Stotz WB, Caillaux L, Aburto J (2006) Interactions between the Japanese abalone Haliotis discus hannai (Ino, 1953) and Chilean species: consumption, competition, and predation. Aquaculture 255:447-455

Streftaris N, Zenetos A, Papathanassiou E (2005) Globalisation in marine ecosystems: the story of non-indigenous marine species across European seas. Oceanogr Mar Biol Annu Rev 43:419-453

Sutherland J, Karlson R (1977) Development and stability of the fouling community at Beaufort, North Carolina. Ecol Monogr 47:425-446

Tyrrell M, Byers J (2007) Do artificial substrates favor nonindigenous fouling species over native species? J Exp Mar Biol Ecol 342:54-60

Valdivia N, Heidemann A, Thiel M, Molis M, Wahl M (2005) Effects of disturbance on the diversity of hard-bottom macrobenthic communities on the coast of Chile. Mar Ecol Prog Ser 299:45-54

Vasquez JA, Castilla JC (1982) Areas de reclutamiento y estructura poblacional de Rhyncocinetes typus Milne Edwards, 1837 (Crustacea: Rhyncocinetidae), in Chile central. Inv Mar 10:1-14

> Wasson K, Fenn K, Pearse J (2005) Habitat differences in marine invasions of Central California. Biol Invasions 7: 935-948

- Witman JD (1987) Subtidal coexistence: storms, grazing, mutualism, and the zonation of kelps and mussels. Ecol Monogr 57:167-187

Witman JD, Dayton PK (2001) Rocky subtidal communities. In: Bertness MD, Gaines SD, Hay ME (eds) Marine community ecology. Sinauer Publishers, Sunderland, MA, p 339-366

Submitted: November 30, 2010; Accepted: January 14, 2011 Proofs received from author(s): March 24, 2011 